\title{
INTEGRATION BETWEEN THE PUBLIC AUTHORITIES AND UNIVERSITIES IN POPULARIZATION OF KNOWLEDGE CONCERNING BIODIVERSITY
}

Rafael Ramos Castellari ${ }^{1}$ Welber Senteio Smith²

Abstract: Brazil is one of the countries with the greatest biodiversity on the planet, housing between 15 and $20 \%$ of the total number of species. Some of that wealth has been inexorably lost, therefore it is necessary to know in depth the natural heritage of the country, to identify the main factors that threaten them and set priorities for action. Knowledge, supported by scientific rigor, is a powerful tool to permanently engage the action of the public authorities in the planning and conservation which, consequently, may introduce more effective instruments of control, supervision and protection process. The Secretary of Environment, in order to subsidize and provide guidelines for environmental actions within the city, articulated with institutions and researchers, during the year of 2013, the theme "Biodiversidade do Município de Sorocaba" ["Biodiversity of the city of Sorocaba"], which resulted in two products published in the official newspaper of the city and a book). These represent important mechanisms that subsidize conservation efforts and environmental education.

\footnotetext{
1 Secretaria do Meio Ambiente. Prefeitura Municipal de Sorocaba. Avenida Campos Salles, 850, Vila Assis, CEP 18025-000, Sorocaba, SP, Brazil.

2 Universidade de Sorocaba. Programa de Mestrado em Processos Tecnológicos e Ambientais. Rodovia Raposo Tavares, km92,5, CEP 18023-000, Sorocaba, SP, Brazil. E-mail: welber.smith@prof.uniso.br. Universidade Paulista. Laboratório de Ecologia Estrutural e Funcional. Avenida Independência, 752, Iporanga, CEP 18103-000, Sorocaba, SP, Brazil. E-mail: welber smith@uol.com.br. Secretaria do Meio Ambiente. Prefeitura Municipal de Sorocaba. Avenida Campos Salles, 850, Vila Assis, CEP 18025-000, Sorocaba, SP, Brazil. E-mail: rcastellari@gmail.com.
} 
Keywords: Conservation; Municipality; Urban Ecosystems.

Revbea, São Paulo, V. 10, № 4: 24-31, 2015.

revista brasileira educação
ambiental 


\section{Introduction}

One of the major current challenges of society is to concatenate biodiversity management with human populations needs (CABRAL et al., 2012, 63-72). Half the world's population is currently living in urban centers and the prospect is that by the year 2030 this population will duplicate (UNFPA, 2007, 1) and the relationship between biodiversity and human being passes today mainly for what happens in the cities.

The urbanization of the landscape fragmented the natural environment, completely changing the appearance of the landscape and its ecological processes to make way for urban space (MCKINNEY, 2002, 883-890.; CABRAL et al., 2012, 63-72.). The biodiversity that occurs in the city especially in its green spaces provide an essential set of ecosystem services to human populations, such as the regulation of local climate, infiltration of storm water and flood protection, air purification and leisure.

In 2002 the Biological Diversity Convention (CBD) was established a reduction in the pace of biodiversity loss by the year 2010. However a recent evaluation using several indicators found that the target was not reached and the speed of biodiversity loss is the fastest already evidenced.

This result reveals that when public policies were adopted has proved inadequate and that the gap between the pressures on biodiversity and responses to mitigation are growing (BUTCHART et al., 2010, 1164-1168). Brazil is one of the countries with the highest biodiversity on the planet, sheltering between 15 and $20 \%$ of the total number of species (MITTERMEIER et al L., 2005, 14-21). Some of that wealth has been lost inexorably, therefore more than ever it is necessary to know in greater depth the natural heritage of the country, identify the main factors that threaten them and establish priority conservation actions.

As the world becomes urbanized, researchers and administrators of cities recognize the importance of providing an urban habitat that favors biodiversity, which could be the beginning of an urban movement in pro of wild flora and fauna. Cities are continuity of natural ecosystems and the main human ecosystem. Valuing urban ecology and its ecosystem services promote sustainable urban planning and management.

The creation of the Department of the Environment and the growing researches realization, promoted in Sorocaba the beginning of a process of inducing discussions, reflections and implement local policies to protect biodiversity. Also contributes to this process the presence of the highest concentration of forest fragments in the state of Sao Paulo and the presence of units representing conservation.

The aim of this study was to promote discussion between researchers working in universities and institutions working on biodiversity of the city articulated by the municipality through the Department of Environment. Inventory of existing species in Sorocaba, spreading through the elaboration of a list of species published in the Journal of the City and a book whose chapters Revbea, São Paulo, V. 10, № 4: 24-31, 2015. 
cover biological groups inventoried, endangered species, geographical distribution and what can be done to expand the knowledge and its conservation. This work distributed to all schools, colleges, universities and libraries of Sorocaba, subsidize projects and environmental education strategies focusing on the theme.

\section{Materials and methods}

The city of Sorocaba is the fourth most populous in the interior of Sao Paulo (preceded by Campinas, Sao Jose dos Campos and Ribeirão Preto), with a population of more than 600 thousand inhabitants, being newly created metropolitan region of Sorocaba, encompassing 29 municipalities.

It has an area of $456.0 \mathrm{~km} \mathrm{2,} \mathrm{with} 349.2$ square kilometers of urban area and rural area of $106.8 \mathrm{~km} 2$ (PREFEITURA MUNICIPAL DE SOROCABA, 2011; SOROCABA, 2013). The city is an important industrial center in the state of Sao Paulo and Brazil.

Sorocaba is bounded by the following municipalities: Porto Feliz, Votorantim, Mairinque, Itu, Aracoiaba da Serra, Salto de Pirapora, Iperó, Alumínio, Capela do Alto, Boituva, Piedade, Ibiúna, Cabreúva and Tatuí (PREFEITURA MUNICIPAL DE SOROCABA, 2011; SOROCABA, 2013).

Is inserted into the Water Resources Management Unit (UGRHI-10) Sorocaba and Middle Tiete. The land use in this basin encompasses intensely urbanized and industrialized areas near Sorocaba and hortifrutifarmers activities, reforestation, natural and cultivated pastures in the countryside.

The Sorocaba region is characterized by the highest concentration of fragments of the state of Sao Paulo and its typical vegetation ecotone with the intersection of different forest types contributes to its strategic role in the scenario of biodiversity conservation (PINA-RODRIGUES et al., 2014, 37-63).

The strategy used was conducted in three stages: 1- articulation of researchers and universities; 2- preparatory meetings and workshops; 3Development of products (published in the city official newspaper and book). The following are detailed each step carried out.

The first stage was conducted by the Department of Environment technicians that raised researchers and universities that develop or developed research with biodiversity in the city. The second step was to convince and articulate the researchers, presenting the project, its products and goals. Two preparatory meetings for explanation and conviction of those involved were performed.

From these meetings was held the First Workshop "Biodiversity in the city of Sorocaba". Attended by teachers, researchers and representatives of environmental agencies responsible for the development of projects related to biodiversity in the city. Mittermeier et al. (2005, 14-21) emphasizes the partnership between government, NGOs and academic community. that unite conservation research (academic community) and its application (government

revista brasileira educação ambiental 
and, increasingly, corporations and industries). Cita still examples of some projects that have been enormously influential in conservation science and its application in Brazil and worldwide. The third step was the development and publication of two products: species list in the Official Gazette of the Municipality and the book "Biodiversity of the city of Sorocaba". The information was obtained from studies conducted by the researchers, encompassing scientific initiation works, dissertations and theses, besides published books and articles.

The methodology implemented in cooperation with scientists and technicians gathered information in three categories: biodiversity in the territory of the city, ecosystem services and governance. The information inventoried was appropriate to the proposed objective and also the desired future applications. Also, was able to answer the major unknowns about the biodiversity of the city. The generated data and forms of presentation are important to facilitate planning and decision made by the public authorities.

\section{Results and discussion}

During the three stages of the project were involved 59 researchers from 12 institutions belonging to national and international institutions (Figure 1, 2 and Table 1). The main information collected were: Compilation of all work carried out in the city that address biodiversity; Socio-Environmental Aspects, and Legal, Species Inventory; Priority conservation areas and the connectivity model fragments.

The 14 chapters of the book provide, clearly and objectively, an overview of the biodiversity of Sorocaba, addressing topics such as: legal grounds, forest remnants with identification of areas of high environmental value, solid surveys of flora and fauna, public policies and activities of the City Zoological Park "Quinzinho de Barros" in the conservation of faunal biodiversity of the region. Moreover, knowledge gaps that should be addressed in future research were identified.

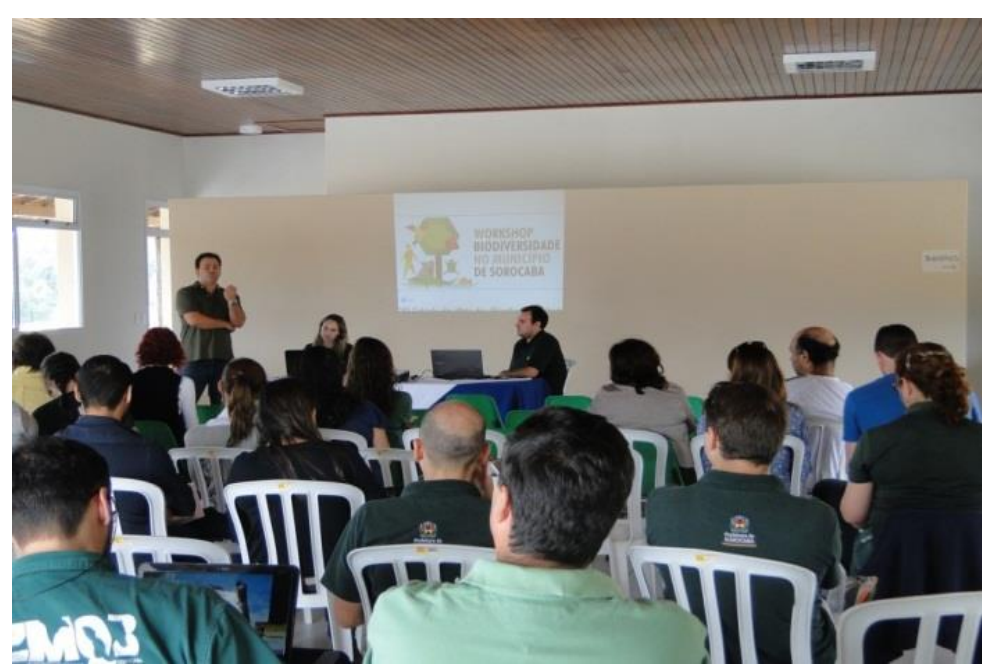

Figure 1: Preparatory Meeting to present the project. 


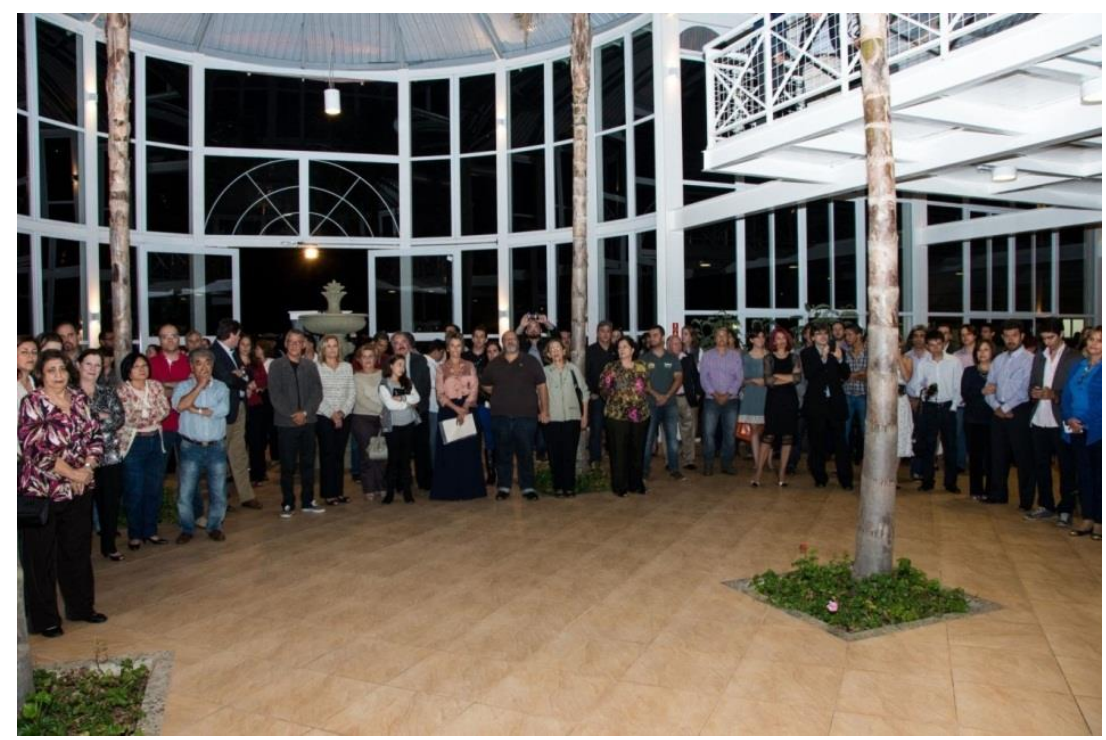

Figure 2: Book Launch "Biodiversity of the City of Sorocaba".

Table 1: Biodiversity in the City of Sorocaba, SP, Brazil.

\begin{tabular}{c|c}
\hline TAXON & Number of species \\
\hline Angiosperm & 441 \\
\hline Phytoplankton & 158 \\
\hline Zooplankton & 21 \\
\hline Arachnida & 58 \\
\hline Insecta & 75 \\
\hline Chilopoda & 03 \\
\hline Gastropoda & 02 \\
\hline Osteichthyes & 53 \\
\hline Bivalvia & 06 \\
\hline Amphibia & 23 \\
\hline Reptilia & 49 \\
\hline Birds & 280 \\
\hline Mammalia & 49 \\
\hline Total & $\mathbf{1 2 1 8}$ \\
\hline Native & $\mathbf{1 1 8 2}$ \\
\hline Exotic & $\mathbf{3 6}$
\end{tabular}

This work contributed to the Environmental Education programs of the city, whose concept has been expanded, in order to guide the environmental education of the citizen. The actions taken from the generation of information resulted in more qualified visits the school community in city parks, besides providing to the teacher local information to the projects development (Figure 3). Educommunicative campaigns were also adopted (Figure 4) with the objective of bringing the population's knowledge of main species arousing respect and admiration for the biodiversity of the county, popularizing scientific knowledge. According to McKinney (2002, 883-890) the impacts of urbanization on native species are poorly studied, but educating a highly urbanized human population about these impacts can greatly improve species conservation in all ecosystems. 


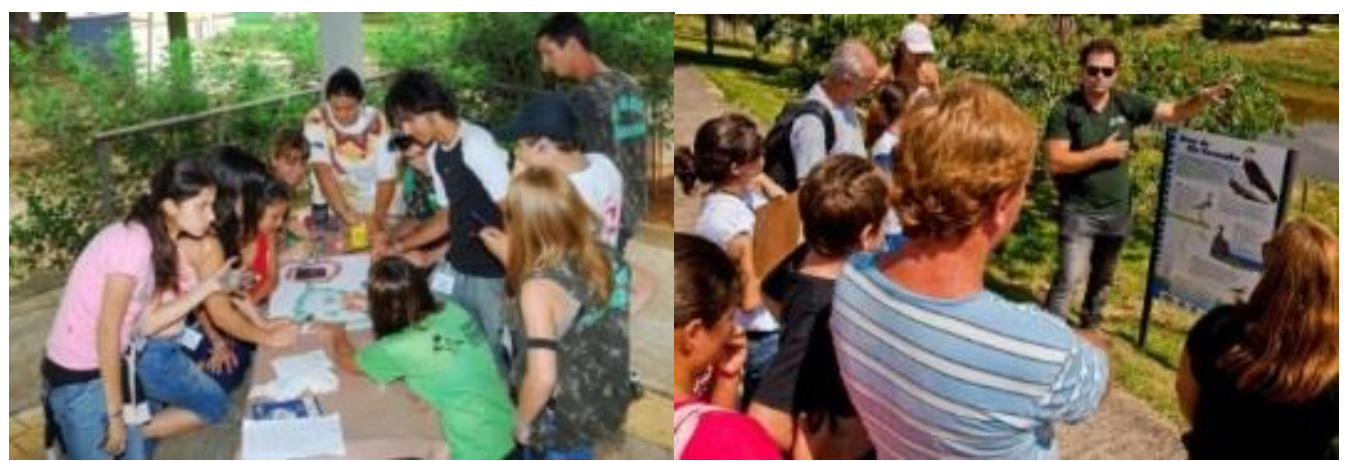

Figure 3: Educational activities held in the parks of the city with biodiversity theme.



Figure 4: Educommunication action with biodiversity theme.

Still have to emphasize the character of novelty of this work since met several researchers, from various entities, around a single theme. This experience not only enriched the discussion of the subjects dealt with in the book, but also the work of the experts who were able to share with colleagues, methodologies, results and the knowledge gained in their professional lives. Sorocaba now has over $90 \%$ of the population living in consolidated urban areas. "Although many believe that the city has completely destroyed its natural systems," they are still alive, but in fragmented and often highly fragile state. From an environmental standpoint, Sorocaba will be sustainable only if the integrity of ecosystems and care for ecosystem services are guaranteed.

The discussions generated by the integration between universities and the public authorities recognize that the role of cities and local authorities, as well as implementation strategies and an action plan will require close collaboration between both. A philosophical question was raised by Tilman (2000, 208-211.): what shouldnt be the role of scientists and science in the development of ethics and policy in biodiversity theme?

Science has much to contribute to dialogues on policy and ethics. Although academic institutions seem to value such contributions less than contributions to peer-reviewed journals, this is shortsighted. Ultimately, society invests in science because advances in

scientific knowledge benefit society. The ethics of science cannot eschew involvement in public discourse. Science must contribute, in an open, unbiased manner, to relevant issues (TILMAN, 2000, 208-211.).

Revbea, São Paulo, V. 10, № 4: 24-31, 2015. 
The way the information was generated and how the book was produced facilitated citizen access to this type of information, creating a survey instrument reference. Another important aspect is to provide guidelines for the preparation of informative material, strategies and educational activities, besides public policies on the issue of biodiversity. The knowledge about the wild flora and fauna is the starting point for the elaboration of public policies in areas of management and conservation.

This work also contributes to the Environmental Education programs of the city, whose concept has been expanded, in order to guide the education of citizens, regardless of their age, within the social context and the ecological and cultural reality in which he lives. This implies the awareness and the formation of knowledge and responsibilities that are being built from concrete experience with the physical and social environment, seeking understanding and solutions to local environmental problems.

\section{References}

BUTCHART, S.H.M., WALPOLE, M., COLLEN, B. et al. (2010). GLOBAL BIODIVERSITY: INDICATORS OF RECENT DECLINES. Science. 328 (5982): 1164- 1168.

CABRAL, M.; PEREIRA, H.M.; CRUZ, C.S.; MATHIAS, M.L. O Índice de Biodiversidade nas Cidades como ferramenta para gestão: o caso da cidade de Lisboa. Ecologi@. Lisboa/Portugal, 6:63-72. Setembro/2012.

UNITED NATIONS. CONVENTION ON BIOLOGICAL DIVERSITY. Conference on Environment and Development. Rio de Janeiro, 1992, 28p.

CONVENTION ON BIOLOGICAL DIVERSITY. Decision X/2 - The Strategic Plan for Biodiversity 2011-2020 and the Aichi Targets. Nagoya/Japan, 2010.

CONVENTION ON BIOLOGICAL DIVERSITY. Decision X/22 - Plan of Action on Subnational Governments, Cities, and Other Local Authorities for Biodiversity. Nagoya/Japan, 2010.

MCKINNEY, M.L. Urbanization, Biodiversity and Conservation. BioScience, 52 (10):883-890. Outubro/2002

MITTERMEIER, R.A.; FONSECA, G.A.B.; RYLANDS, A.B.; BRANDON, K. Uma breve história da conservação da biodiversidade no Brasil. Megadiversidade. Belo Horizonte/Brasil., 1(1): 14-21. Julho/2005.

PIÑA-RODRIGUES, F.C.M.; ALMEIDA, V.P.; FREITAS, N.P.; LOURENÇ, R. W.; MANDOWSKY, D. LOPES, G.R.; GRIMALDI, M.; SILVA, D.C.C. Remanescentes florestais: identificação de áreas de alto valor para a conservação da diversidade vegetal no município de Sorocaba. In: SMITH; W.S.; MOTTA JR, V.D.; CARVALHO, J.L. (org). Biodiversidade do Município de Sorocaba, Edição: 1. Sorocaba. 2014. 37-63. 
SOROCABA. Prefeitura Municipal de Sorocaba. Plano Diretor Ambiental de Sorocaba. Produto 5 - Macrozoneamento e Propostas. 58p. Outubro/2011.

SOROCABA. Secretaria Municipal de Meio Ambiente. Projetos. 2013. Disponível em: <http://www.meioambiente.sorocaba.sp.gov.br>. Acesso em 03 de Maio de 2013.

TILMAN, D. Causes, consequences and ethics of biodiversity. Nature, 405:208211. Maio/2000.

UNFPA - UNITED NATIONS POPULATION FUND. State of World Population 2007: Unleashing the potential of urban growth. New York: UNFPA, 2007. 